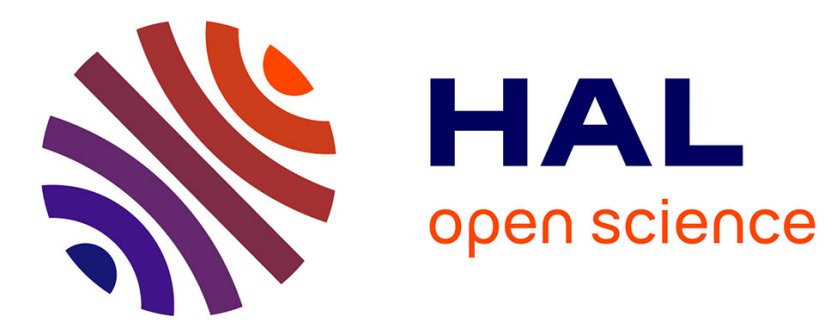

\title{
A systemic perspective for mass customization: an approach for product lines definition
}

\author{
Antonio Giovannini, Alexis Aubry, Hervé Panetto, Hind El Haouzi
}

\section{To cite this version:}

Antonio Giovannini, Alexis Aubry, Hervé Panetto, Hind El Haouzi. A systemic perspective for mass customization: an approach for product lines definition. INSIGHT - International Council on Systems Engineering (INCOSE), 2013, 16 (4), pp.10-12. 10.1002/inst.201316410 . hal-00920965

\section{HAL Id: hal-00920965 https://hal.science/hal-00920965}

Submitted on 20 Dec 2013

HAL is a multi-disciplinary open access archive for the deposit and dissemination of scientific research documents, whether they are published or not. The documents may come from teaching and research institutions in France or abroad, or from public or private research centers.
L'archive ouverte pluridisciplinaire HAL, est destinée au dépôt et à la diffusion de documents scientifiques de niveau recherche, publiés ou non, émanant des établissements d'enseignement et de recherche français ou étrangers, des laboratoires publics ou privés. 
A systemic perspective for mass customization: an approach for product lines definition Antonio Giovannini ${ }^{1,2,3}$, Alexis Aubry ${ }^{1,2}$, Hervé Panetto ${ }^{1,2}$, Hind El Haouzi ${ }^{1,2}$

${ }^{1}$ Université de Lorraine, CRAN, UMR 7039, Campus sciences

B.P. 70239, Vandœuvre-lès-Nancy Cedex, 54506, France

${ }^{2}$ CNRS, CRAN, UMR 7039, France

${ }^{3}$ TRANE SAS, rue des Amériques, 88190 Golbey, France

(e-mail: \{antonio.giovannini; alexis.aubry; herve.panetto; hind.elhaouzi\}@incose.org)

Nowadays, the customer-oriented market and the stress on performances lead a lot of enterprises to adopt the Mass Customization (MC) (Davis 1987) strategy as identified in (Tseng and Jiao 2001). Ideally $\mathrm{MC}$ is a business approach that provides a product customization capability like an engineer-to-order organization (ETO - the product is designed at each order entry), preserving the mass production efficiency. In this paper, we cope with the formalization of the link between customer needs and the customized product variant that can be configured starting from them. The aim is to propose a way to build this link for formalizing the product variety in the customer domain. This paper is based on industrial cases of Trane, a multinational company that develops, manufactures and commercializes air-handling systems.

In MC, a commonly accepted solution for managing product variety is develop a configuration system in which customer can enter values for some options in order to define a product variant. A configuration system manages various product configurations accordingly with the rules formalized by designers. These rules compose a model that represents the product variety. Usually, this kind of product model is named in many different ways, e.g. product family (Hong et al. 2008), configurable product model (Aldanondo and Vareilles 2008) or product line (Pohl, Bockle, and Van Der Linden 2005; Mazo et al. 2012). The name Product Line (PL) will represent here all these types of models.

According to the aim of the paper, current works on PL can be classified on the distance between the customer needs and the input of the PL (i.e. values of proposed options required by the system to configure a product). Three groups, based on the main system definition models (i.e. requirements, logical architecture, technical architecture (Pyster et al. 2012)) can be identified on the basis of this dimension:

- Product component features (i.e. technical architecture) as input (e.g. (Zhu et al. 2008): at this stage the customer (not supposed to be an expert) is not able to understand the interaction between components and evidently he is not able to understand their impacts on his needs;

- Product functions (i.e. logical architecture) as input (e.g. (Li et al. 2006)): the customer is not able to know how functions can satisfy its needs and especially about how functions interact for doing so;

- Product specification (i.e. requirements) as input (e.g. (Qin and Wei 2010; Hong et al. 2008)): to the customer is provided the knowledge about the effects of how the product functions (and so product components) interact for performing the product behaviour, of which specifications are the description; in this case, the customer still is not able to know the impact of the product specification on his needs.

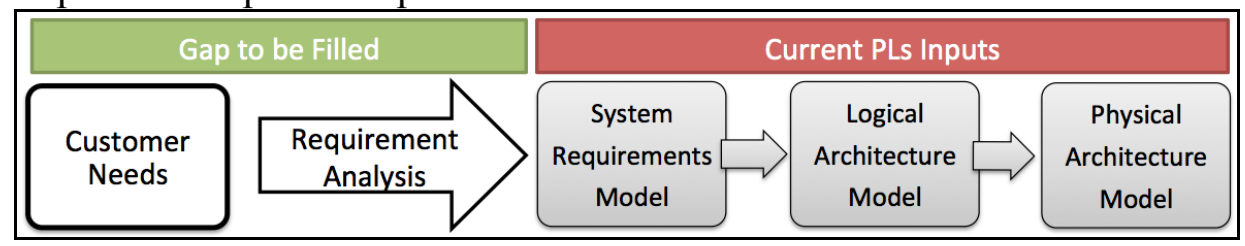

Fig. 1 - showing the gap of current PL approaches 
Starting from this classification, we can identify a gap to be filled (Fig. 1) in order to formalize the link between customer needs and system requirements. In order to fill this gap, in the configuration system:

- manufacturers can use market research (e.g. (Helo et al. 2010)), but therefore the manufacturer designs the products and after looks for potential customers;

- manufacturers can optimize customer satisfaction (e.g. (Hong et al. 2008)), but that implies they are able to represent and to assess the feeling of satisfaction of each customer;

- a seller is charged to fill this gap, performing a real requirement analysis process (Haskins, Forsberg, and Engineering 2011);

- in the worst (but very usual) case, customers have to fill this gap.

Other approaches, from the business sciences (Bergvall-Kareborn et al., 2009; Stahlbröst, 2008), are involving customers in each design stage. But, for instance, let us consider the case of an air-conditioner manufacturer, the question to put to the customer is: how is the air that you want to breathe? In our opinion, customers are not able to answer at this kind of questions. We are convinced that customers have to be expert only of their environment. Therefore questions to be put are: how is the room that you want to heat? Therefore, in this work, we propose a method to build PLs that formalizes the variety directly in the customer domain, i.e. properties of the environment.

Here we propose a method based on definitions such as system, environment, interaction, purpose and black-box coming from cybernetics and system theory (Giovannini et al., 2013). Starting from the system purpose (e.g. a predefined air quality), an engineer can identify needed interactions (e.g. based on some principles of physics) between the purpose fulfilment and the system features (i.e. the goal of the configuration process). Here the system to be configured is seen like a black-box, because in the MC scenario, we suppose that the link from the system specifications (i.e. features) and the manufactured product (i.e. how to manufacture offered products) is built during the design stage (and not at each order entry). In order to represent a PL we use a mathematical representation typical of control theory, i.e. state-space models (Levine 1996) as follows:

- The system (in state-space models) is the customer environment (e.g. customer room to heat)

- States functions model a parametric interaction (representing the PL variety) between the environment description (built taking into consideration information from the customer) and configured system specifications (e.g. stationary features of the air-conditioner);

- Input functions represent the system specifications that can be managed dynamically;

- The output function is based on state values in an instant of time.

- A set of defined state values (e.g. room temperature, humidity) or one output value (e.g. air comfort) defines the purpose of the configured system.

In order to define this model, a well-defined purpose (e.g. values for humidity and temperature of the customer room) has to be identified. By means of the domain knowledge, the engineer identifies the parametric interactions between the customer environment (e.g. room orientation and placement in the building, room usage, etc.) and the system specifications (e.g. features of the air-conditioner to be configured). These interactions have to be formalized as state functions. At each order entry, starting from customer information, values for environment parameters are determined. Starting from these, system specifications are defined by the values that allow to achieve the purpose taking into account the environment features formalized in the states functions. 
Deploying this method, a customer has only to describe its environment to configure the right product (from the engineer point of view). Our future work will address for formalisation of the approach, based on an extension of the ONTO-PDM product ontology (Panetto et al, 2012), and validating this approach on a real case from Trane.

\section{References}

Aldanondo, M., and E. Vareilles. 2008. "Configuration for Mass Customization: How to Extend Product Configuration Towards Requirements and Process Configuration." Journal of Intelligent Manufacturing 19 (5): 521-535.

Bergvall-Kareborn, B., M. Hoist, and A. Stahlbrost. 2009. "Concept Design with a Living Lab Approach." In 42nd Hawaii International Conference on System Sciences HICSS'09., 1-10. http://ieeexplore.ieee.org/xpls/abs_all.jsp?arnumber=4755508.

Davis, Stanley M. 1987. Future Perfect. Addison-Wesley.

Giovannini A., Aubry A., Panetto H., El Haouzi H. 2013. "Mass customisation in sustainable networked enterprises" in 14th IFIP Working Conference on Virtual Entreprise, PROVE'13, Collaborative Systems for Reindustrialization, Dresden, Germany

Haskins, C., K. Forsberg, and International Council on Systems Engineering. 2011. Systems Engineering Handbook: A Guide for System Life Cycle Processes and Activities; INCOSE-TP-2003-002-03.2. 1.

Helo, P. T., Q. L. Xu, S. J. Kyllönen, and R. J. Jiao. 2010. "Integrated Vehicle Configuration System-Connecting the Domains of Mass Customization." Computers in Industry 61 (1): 44-52.

Hong, G., L. Hu, D. Xue, Y. L. Tu, and Y. L. Xiong. 2008. "Identification of the Optimal Product Configuration and Parameters Based on Individual Customer Requirements on Performance and Costs in One-of-a-kind Production." International Journal of Production Research 46 (12) (June 15): 3297-3326. buh.

Levine, William S., ed. 1996. The Control Handbook. 1st ed. CRC Press.

Li, Bin, Liping Chen, Zhengdong Huang, and Yifang Zhong. 2006. "Product Configuration Optimization Using a Multiobjective Genetic Algorithm." The International Journal of Advanced Manufacturing Technology 30 (1): 20-29. doi:10.1007/s00170-0050035-8.

Mazo, R., C. Salinesi, D. Diaz, O. Djebbi, and A. Lora-Michiels. 2012. "Constraints: The Heart of Domain and Application Engineering in the Product Lines Engineering Strategy." International Journal of Information System Modeling and Design (IJISMD) 3 (2): 33-68.

Panetto H., Dassisti M., Tursi A. 2012. "ONTO-PDM: product-driven ONTOlogy for Product Data Management interoperability within manufacturing process environment." Advanced Engineering Informatics 26 (2): 334-348. doi: 10.1016/j.aei.2011.12.002

Pohl, K., G. Bockle, and F. Van Der Linden. 2005. Software Product Line Engineering. Vol. 10. Springer. http://cs5292.userapi.com/u11728334/docs/7ca820593ad0/Klaus_Pohl_Software_Pro duct_Line_Engineering.pdf.

Pyster, A., D. Olwell, A. Squires, N. Hutchison, S. Enck, and J. Anthony. 2012. "A Guide to the Systems Engineering Body of Knowledge (SEBoK). Version 1.0." Stevens Institute of Technology.

Qin, Y. H., and G. X. Wei. 2010. "Product Configuration Based on Modular Product Family Modelling." Journal of Computational Information Systems 6 (7): 2321-2331.

Staahlbröst, Anna. 2008. "Forming Future IT: The Living Lab Way of User Involvement." http://epubl.ltu.se/1402-1544/2008/62/index-en.html. 
Tseng, M. M., and J. Jiao. 2001. "Mass Customization.” Handbook of Industrial Engineering, 3rd Edition, New York: Wiley: 684-709.

Zhu, Bin, Zhan Wang, Haicheng Yang, Rong Mo, and Yanwei Zhao. 2008. "Applying Fuzzy Multiple Attributes Decision Making for Product Configuration." Journal of Intelligent Manufacturing 19 (5): 591-598. doi:10.1007/s10845-008-0132-2. 